\title{
Fish Diversity of River Siyom of Arunachal Pradesh India: A Case Study
}

\author{
K. Bagra ${ }^{1}$ and D.N. Das ${ }^{2}$ \\ ${ }^{1}$ Arunachal Pradesh Biodiversity Board, SFRI, Itanagar- 791113, India \\ E-mail:bagrakb@gmail.com \\ ${ }^{2}$ Department of Zoology, Rajiv Gandhi University, Rono Hills Itanagar- 791112, India \\ E-mail:dndas321@rediffmail.com
}

Received: 22.09.2010, Accepted: 03.11.2010

\begin{abstract}
Arunachal Pradesh being rich in fishery resources biophysically, the status of the fish diversity is not known from all the water bodies. A case study was undertaken in the river Siyom $\left(28^{\circ} 11^{\prime} 25^{\prime \prime}-28^{\circ} 10^{\prime} 52^{\prime \prime} \mathrm{N}\right.$ and $\left.94^{\circ} 45^{\prime} 17^{\prime \prime}-97^{\circ} 47^{\prime} 51^{\prime \prime} \mathrm{E}\right)$ of West Siang district, Arunachal Pradesh from 2002 to 2004 with the fragmentary work till 2007. For the purpose, sampling of fish was done from the river time to time using local contraption along with modern nets. A total of 44 species of fishes belongs to 9 families were identified. Fishes of family Cyprinidae were found to be dominant followed by Balitoridae. Some of the fish species were found very rare in the river, which may be due to various anthropogenic factors. Therefore, in addition to social restriction on community fishing some awareness measures need to be taken to prevent the destructive fishing activities in the river.
\end{abstract}

Key words: Hill stream fishes, Aalo West Siang, Brahmaputra river system

\section{Introduction}

The entire territory of Arunachal Pradesh forms a complex hill system with varying elevation, traversed throughout by a number of rivers and rivulets. The unique drainage system of the state falls under upper Brahmaputra river system constituted by ten major river basins. The Himalayan region holds variety of fish species of which most are cold-water hill stream fishes. The river system of Arunachal Pradesh is enriched with 213 species of fishes (Bagra et al., 2009). The state has sixteen districts and most of them have been named after the rivers of the state. Of them, the district West Siang has varied geographical features from very low land of $120 \mathrm{~m}$ to an altitude of $4000 \mathrm{~m}$ covering an area of $8325 \mathrm{~km}^{2}$. The area has numbers of river and rivulets viz., Siyom, Sipu, Hoo, Hirik, Hiru, Kidi, Ego, Siji etc., having rich biological diversity of fishes. Among the diversified fish fauna many species possess characteristics features to become high food and ornamental value.

The Siyom river $\left(28^{\circ} 11^{\prime} 25^{\prime \prime}\right.$ $28^{\circ} 10^{\prime} 52^{\prime \prime} \mathrm{N}$ and $\left.94^{\circ} 45^{\prime} 17^{\prime \prime}-97^{\circ} 47^{\prime} 51^{\prime \prime} \mathrm{E}\right)$ (Fig. 1, A-B) in West Siang district of Arunachal Pradesh is the largest river in the district and is popularly known as 'Yomgo'. The river enters the state meandering through steep gorges, crossing Indo-China international boundary at Mechuka region at an altitude of $3700 \mathrm{~m}$. The slop gradient of the river as recorded by Geological Survey 
of India is $2^{\circ}, 4.3^{\circ}, 7^{\circ}, 3.5^{\circ}$. The river has many important tributaries like Sheit at Tato $(1320 \mathrm{~m})$, Gasi-gate at Payum $(1035 \mathrm{~m})$, Hiru at Kamki $(270 \mathrm{~m})$, Hirik at Kamba $(270 \mathrm{~m})$ and Sipu at Aalo $(223 \mathrm{~m})$. It culminates to its confluence $30 \mathrm{~km}$ towards northeast from Aalo at Panging joining the mighty river Siang. The study site Aalo (Along) $\left(28^{\circ} 10^{\prime} 15^{\prime \prime} \mathrm{N}\right.$ and $\left.94^{\circ} 47^{\prime} 46^{\prime \prime} \mathrm{E}\right)$ is the district headquarters of West Siang district with a population of 18,000 as per 2001 census. 'Galo' a major tribe of the state dominates the region.

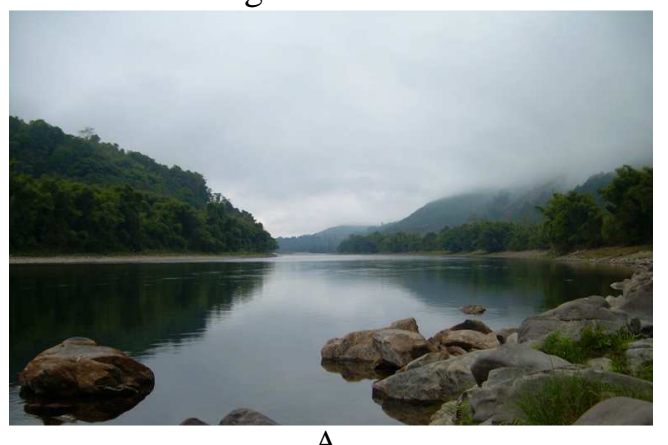

A

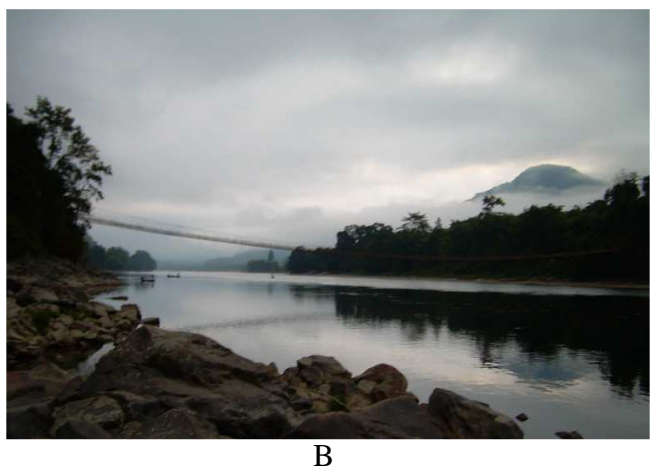

Figure 1 (A-B). Siyom river at Kabu fishing site

\section{Materials and Methods}

Three sites within $10 \mathrm{~km}$ river length (Fig. 2) of Siyom river were selected for fish sampling viz., Site 1- the main water body, Site 2- the confluence site with a bigger river and Site 3- the confluence site with a stream. Fishes were collected using different fishing gears like Gill net, cast net, edir and raju as per suitability and need in

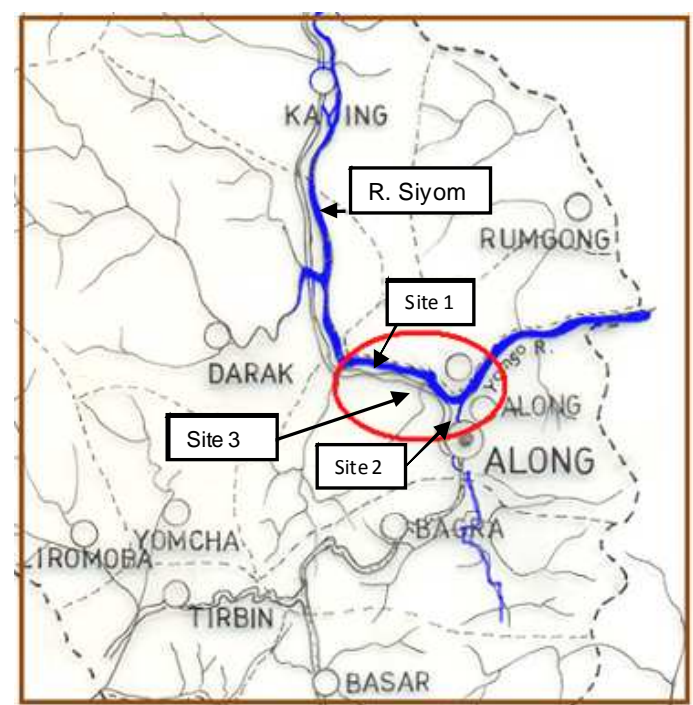

Figure 2. Map of Aalo (Along) and its nearby area showing the sampling sites in river Siyom

different water bodies. Edir is an indigenously designed fishing gears made from bamboo in the form of basket. Once fish get entered inside, it will be blocked from coming out by small conical spiny valve inside. Fishes ranging from 2 to $25 \mathrm{~cm}$ body length can be trapped with this gear. Raju, another indigenous fishing gear used is a conical shaped gear used by Galo womenfolk. It is used in small rivers and streams to collect shrimps, crabs and small fishes especially of the family Sisoridae and Balitoridae. Collections were also done by damming the river. Samplings were done for 4 to 5 times from the same site within the time interval of 5 to $10 \mathrm{~min}$ in a day. Simultaneously, physico-chemical parameters of water viz., $\mathrm{pH}$, dissolve oxygen, alkalinity and temperature were analysed following APHA (1998). Samplings were conducted continuously for 
K. Bagra and D.N. Das / Our Nature (2010) 8: 164-169

two years from 2002 to 2004. However, fragmentary works like random sampling from time to time were conducted till 2007. The fish, thus collected were preserved in $10 \%$ formalin following Jayaram (1999). Taxonomical studies were performed as per Talwar and Jhingran (1991), Jayaram (1999), and Nath and Dey (2000). Fishes collected are kept in Rajiv Gandhi University Museum of Fishes, Rono Hills, Itanagar.

\section{Results and Discussion}

Forty-four species of fishes belong to 9 families were recorded in the water body of Siyom river (Tab. 1) that falls under 4 orders viz., Angulliformes, Cypriniformes, Siluriformes and Perciformes (Fig. 3, A-J). Exotic fishes like Cyprinus carpio was also recorded that probably came out from fish pond to the river and their number of catch was negligible. Statistical analysis reveals that the variance in fish distribution in different habitats and sites are insignificant. Based on the sampling, the abundance of the fishes in genus wise in the Siyom river can be grouped in three categories as: High (Garra, Tor, Barilius, Danio), Medium (Noemacheilus, Aborichthys, Labeo, Semiplotus), and Low (Schizopyge, Botia).

Table 1. Fishes of Siyom river

\begin{tabular}{ll}
\hline SN Name of the species & \multicolumn{1}{l}{ Order: ANGUILLIFORMES } \\
& Family: Anguillidae \\
1 & Anguilla bengalensis (Gray, 1831) \\
\hline & Order: CYPRINIFORMES \\
& Family: Cyprinidae \\
2 & Barilius barna (Hamilton, 1822) \\
3 & Barilius bendelisis (Hamilton, 1807) \\
4 & Barilius vagra (Hamilton, 1822) \\
5 & Danio dangila (Hamilton, 1822) \\
6 & Danio rerio (Hamilton, 1822) \\
7 & Devario aequipinnatus (McClelland, 1839)
\end{tabular}

8 Devario devario (Hamilton, 1822)

9 Cyprinus carpio Linnaeus, 1758

10 Tor putitora (Hamilton, 1822)

11 Tor tor (Hamilton, 1822)

12 Neolissochilus hexagonolepis (McClelland, 1839)

13 Puntius sarana (Hamilton, 1822)

14 Semiplotus semiplotus (McClelland, 1839)

15 Crossocheilus latius (McClelland, 1842)

16 Bangaba dero (Hamilton, 1822)

17 Labeo pangusia (Hamilton, 1822)

18 Schizothorax progastus (McClelland, 1839)

19 Schizothorax richardsonii (Gray, 1832)

20 Garra annandalei (Hora, 1921)

21 Garra gotyla (Gray, 1830)

22 Garra kempi (Hora, 1921)

23 Garra lissorhynchus (McClelland, 1842)

24 Garra naganensis (Hora, 1921) Family: Psilorhynchidae

25 Psilorhynchus balitora (Hamilton, 1822)

26 Psilorhynchus arunachalensis (Nebeshwar et al., 2007)

\section{Family: Balitoridae}

27 Acanthocobitis botia (Hamilton, 1822)

28 Aborichthys elongatus (Hora, 1921)

29 Aborichthys kempi (Chaudhuri, 1913)

30 Noemacheilus devdevi (Hora, 1935)

31 Schistura rupecola (McClelland, 1838)

32 Schistura manipurensis (Chaudhuri, 1912)

33 Lepidocephalichthys arunachalensis (Dutta and Burman,1984)

34 Botia rostrata (Gunther, 1868)

Order: SILURIFORMES

Family: Bagridae

35 Batasio fasciolatus ( $\mathrm{Ng}, 2006)$

Family: Siluridae

36 Pterocryptis gangelica (Peters, 1861)

Family: Family: Amblycipitidae

37 Amblyceps arunachalensis (Nath and Dey, 1989)

38 Amblyceps apangi (Nath and Dey, 1989)

Family: Sisoridae

39 Bagarius bagarius (Hamilton, 1822)

40 Pseudecheneis sulcatus (McClelland, 1842)

\section{Order: PERCIFORMES}

Family: Channidae

41 Channa marulius (Hamilton, 1822)

42 Channa striatus (Bloch, 1793)

43 Channa punctata (Bloch, 1793)

It is evident from the present investigation that the ichthyofauna of Siyom 
river is dominated with cold water Hill

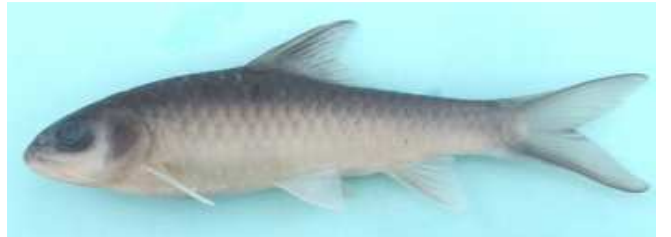

A. Neolissochilus hexagonolepis

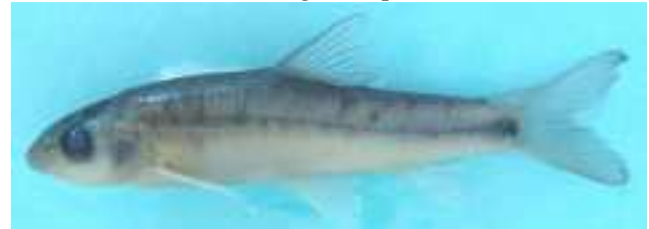

C. Schizothorax richardsonii

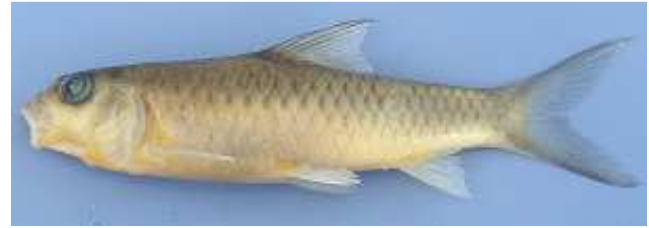

E. Tor putitora

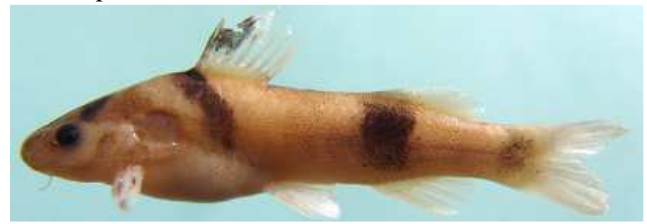

G. Batasio fasciolatus

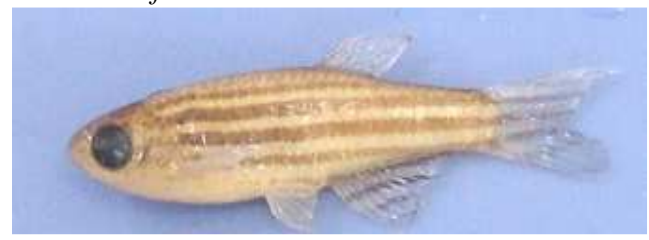

I. Danio rerio stream fishes that may be probably due to

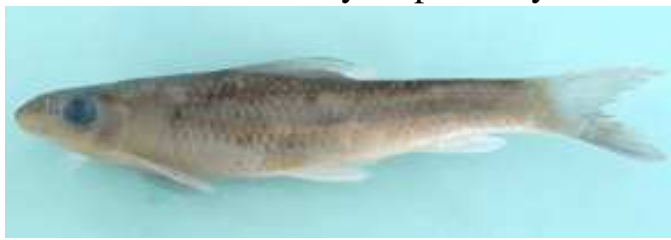

B. Crossocheilus latius

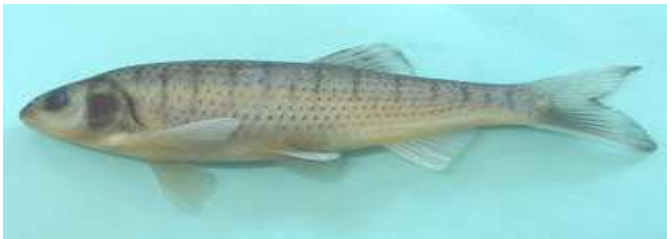

D. Barilius bendelisis

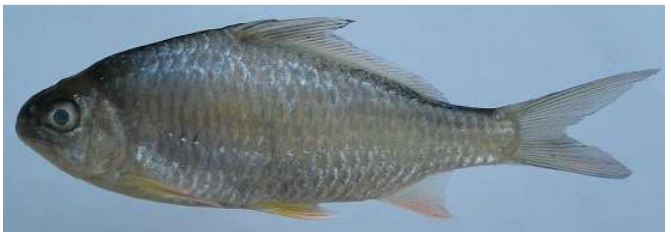

F. Semiplotus semiplotus

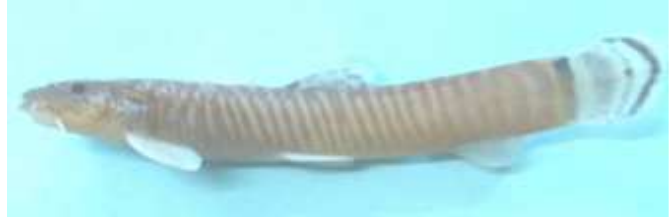

H. Aborichthys elongatus

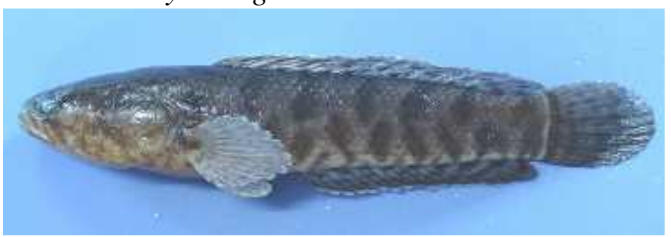

J. Channa punctata

Figure 3 (A-J). Fishes of river Siyom

the nature of the river with high water current and gradient, low water temperature etc. The water temperature varies from 9 to $16^{\circ} \mathrm{C}$ in different season of the year (Tab. 2 ). The samplings showed the dominance of some species in specific habitat. Labeo were sampled highest in site 1, probably they prefers deepen water. Garra dominated the site 2 , followed by site 1 , as they are adapted well in both deep as well as turbulent rivers (Parihar, 1999). Fishes of family Balitoridae were mostly found in site 3 . The sampling showed different numbers of fishes in different sites (Tab. 3) and the statistical analysis (ANOVA) didn't support that the variance in the abundance of different genus in three different sites is significant (Misra and Misra, 1989). 
Table 2. Water parameters of the river Siyom

\begin{tabular}{|c|c|c|c|c|}
\hline Season & Temp. & DO & pH & Alkalinity \\
\hline Winter & $9-11^{\circ} \mathrm{C}$ & $\begin{array}{c}14.7 \pm 1.11 \mathrm{~m} \\
\mathrm{~g} / \mathrm{l}\end{array}$ & $6.0-7.5$ & $\begin{array}{c}42.0 \pm 2.22 \\
\mathrm{mg} / \mathrm{l}\end{array}$ \\
\hline Summer & $20-26^{\circ} \mathrm{C}$ & $\begin{array}{c}10.8 \pm 1.23 \mathrm{~m} \\
\mathrm{~g} / \mathrm{l}\end{array}$ & $6.5-7.5$ & $\begin{array}{c}45.3 \pm 3.12 \\
\mathrm{mg} / \mathrm{l}\end{array}$ \\
\hline
\end{tabular}

Table 3. Average sampling of different genera (per week) from river Siyom

\begin{tabular}{|c|c|c|c|c|c|}
\hline \multirow{2}{*}{ SN } & \multirow{2}{*}{ Genus } & \multicolumn{3}{|c|}{ Habitat } & \multirow{2}{*}{ Tota } \\
\hline & & $\overline{\text { Site } 1}$ & Site 2 & Site 3 & \\
\hline 1 & Schizothorax & 5 & 6 & 0 & 11 \\
\hline 2 & Labeo & 16 & 10 & 0 & 26 \\
\hline 3 & Danio & 7 & 26 & 71 & 104 \\
\hline 4 & Barilius & 17 & 31 & 10 & 58 \\
\hline 5 & Semiplotus & 6 & 12 & 0 & 18 \\
\hline 6 & Tor & 17 & 30 & 2 & 49 \\
\hline 7 & Garra & 25 & 40 & 7 & 72 \\
\hline 8 & Aborichyths & 0 & 12 & 27 & 39 \\
\hline 9 & Noemachalus & 0 & 12 & 30 & 42 \\
\hline 10 & Acanthocobitis & 0 & 0 & 10 & 10 \\
\hline 11 & Botia & 0 & 2 & 0 & 2 \\
\hline 12 & Amblyceps & 0 & 2 & 8 & 10 \\
\hline 13 & Bagarius & 1 & 0 & 0 & 1 \\
\hline 14 & Channa & 0 & 0 & 7 & 7 \\
\hline & Total & 94 & 183 & 172 & \\
\hline
\end{tabular}

The test of variance infers: (i) $\mathrm{F}$ for between genus: the degree of freedom, $\mathrm{n} 1=13$ and $\mathrm{n} 2=26$. The tabulated $\mathrm{F}$ for 13 and 26 degree of freedom is 2.2 at $0.05 \mathrm{p}$ significance level. The calculated $\mathrm{F}$ is 1.92 , which is lower than the tabulated value. So, it can be concluded that the variance in different genus is insignificant. (ii) $\mathrm{F}$ for between habitats: the degree of freedom, $\mathrm{n} 1=13$ and $\mathrm{n} 2=26$. The tabulated $\mathrm{F}$ for 13 and 26 degree of freedom is 2.2 at $0.05 \mathrm{p}$ significance level. The calculated $\mathrm{F}$ is 1.04 , which is lower than the tabulated value. So, it can be concluded that the variance in different habitats is also insignificant. This means that in spite of the differences in the number of the fishes sampled, the overall variance in abundance is more or less similar. This infers that the diversity of different fish species in different sites of Siyom River is more or less similar.

The information collected from the local people and fisherman of the region reveals high decline in the fish population in last decade. This may be due to uncontrolled fishing to meet the high market demand of the local fishes. Moreover, the fishing activities were intensified with the introduction of modern fishing gears and techniques. As per an estimate, good quantity of the fish requirements of Aalo fish market comes from Siyom river only. This adds to the fishing chaos in the fisherman that finally helps the local community in generating good revenue. As an example, a village named $K a b u$ in the river bank of Siyom earns annual revenue amounting higher than Rs. 2 lacks as fishing tax from the fisherman from an area of 2 $\mathrm{km}$. river lengths.

In view of the existing practices there is urgent need to take up certain conservation approach to control the drastic drop down in fish population and to save some of the vulnerable species from wiping out of the region. Though, there are certain legal restrictions in few areas, but it remained un-productive due to lack of uniformity in its implementation in different river stretches. The use of indigenous fishing gears, which are eco-friendly as well as sustainable need to be encouraged instead of modern gears. Captive fishery practices also need to be developed, so that the load of demand directly on the fishes of the river could be minimized up to certain extent.

\section{Acknowledgements}

The authors are thankful to Fisheries and Aquatic Ecology Division, Department of Zoology, Rajiv Gandhi University, Rono 
Hills, Itanagar for providing infrastructural and other logistic support for the work and to Mr. H. Loyi, Assistant Professor, Botany, J.N. College, Pasighat, Arunachal Pradesh for contributing valuable photographs of Siyom river.

\section{References}

APHA 1998. Standard methods for the examination of water and waste water. $20^{\text {th }}$ ed. American Public Health Association, American Water Work Association and Water Environment Federation, Washington. $361 \mathrm{p}$.

Bagra, K., K. Kadu, K.N. Sharma, B.A. Laskar, U.K. Sarkar and D.N. Das 2009. Ichthyological survey and review of the checklist of fish fauna of Arunachal Pradesh, India. Check List
5(2): 330-350.

Jayaram, K.C. 1999. Fish identification. The fresh water fishes of the Indian region. Narendra Publishing House, Delhi. 55 p.

Misra, B.N. and M.K. Misra 1989. Introductory practical Biostatistics. Naya Prokash, Calcutta. pp.110-117.

Nath, P. and S.C. Dey 2000. Fish and fisheries of North East India (Arunachal Pradesh). Narendra Publishing house, Delhi. 217 p.

Parihar, R.P. 1999. A textbook of fish biology and Indian fisheries. Central Publishing house, Allahbad. pp. 266-306.

Talwar, P.K. and A.G. Jhingran 1991. Inland fishes of India and adjacent countries. Volume I and II. Oxford and IBH Publishing Company Pvt. Ltd., New Delhi. 1158 p. 